POLITYKA ENERGETYCZNA - ENERGY POLICY JOURNAL

$2021 \uparrow$ Volume $24 \uparrow$ Issue $2 \uparrow 97-116$

DOI: $10.33223 / \mathrm{epj} / 133473$

Justyna CADER $^{1}$, Piotr OlCZAK ${ }^{2}$, Renata KONECZNA ${ }^{3}$

\title{
Regional dependencies of interest in the "My Electricity" photovoltaic subsidy program in Poland
}

ABSTRACT: In less than a decade, the photovoltaic sector has transformed into a global business. The dynamics of its development vary depending on the country. According to estimates, the value of the photovoltaic micro-installations market in Poland at the end of 2019 exceeded PLN 2.8 billion. In the first half of 2020, the PV sector recorded dynamic growth with a total capacity of the micro-installations of $2.5 \mathrm{GWp}$. Government subsidies were among the factors contributing to the expansion of the PV sector. In Poland, there are many financial ways to intensify the construction of new renewable energy source installations, among others: feed-in tariff, grants, and loans. An example of photovoltaic grant support in Poland is the "Mój Prąd" [My Electricity] program created in 2019 with a budget of PLN 1.1 billion. The interest in the "My Electricity" program in individual provinces may vary, depending on socio-economic factors, technological and environmental resources, and the level of innovation. The research motivation of this article is a comparison of provinces in Poland according to selected energy, environmental, innovation, and socio-economic indicators and

Corresponding Author: Justyna Cader; e-mail: jcader@min-pan.krakow.pl

${ }^{1}$ Mineral and Energy Economy Research Institute of the Polish Academy of Sciences, Kraków, Poland, Faculty of Geology, University of Warsaw, Poland; ORCID iD: 0000-0001-5236-3223; e-mail: jcader@min-pan.krakow.pl

2 Mineral and Energy Economy Research Institute of the Polish Academy of Sciences, Kraków, Poland; ORCID iD: 0000-0002-4926-0845; e-mail: olczak@min-pan.krakow.pl

3 Mineral and Energy Economy Research Institute of the Polish Academy of Sciences, Kraków, Poland; ORCID iD: 0000-0001-8334-5618; e-mail: rkoneczna@min-pan.krakow.pl

2021. The Author(s). This is an open-access article distributed under the terms of the Creative Commons Attribution-ShareAlike International License (CC BY-SA 4.0, http://creativecommons.org/licenses/by-sa/4.0/), which permits use, distribution, and reproduction in any medium, provided that the Article is properly cited. 
to show how these factors affect individual interest in the "My Electricity" photovoltaic development program in provinces.

The highest correlation is for the total installation power under the "My Electricity" program and Gross Domestic Product and Human Developed Index. The highest correlation coefficient from RIS indicators and photovoltaic data programs was achieved for "R\&D expenditure in the business sector". The population was closely correlated with the total installation power and the grant value of the "My Electricity" program.

KEYWORDS: renewable energy, photovoltaics, correlation analysis, "My Electricity" program, RIS indicators

\section{Introduction}

The continuous increase in energy demand and the prospect of the exhaustion of fossil fuel reserves significantly increase the trend of searching for new, ecological energy technologies. The interest in renewable energy sources is also related to caring for the environment and searching for long-term potential actions for sustainable development (Lin and Ren 2020; Østergaard et al. 2020; Canales et al. 2020). One of the important renewable energy technologies is photovoltaics (Allied Market Research 2019; Olczak et al. 2020a). The pace and nature of its expansion around the world vary, including across the EU. Government subsidies and continuous innovation were among the factors contributing to its growth. Various studies were conducted on the analysis of the dependence of selected factors and renewable energy sources. The studies especially worth mentioning are the analyses of the relationship between renewable energy and human development (Kazar and Kazar 2014; Sasmaz et al. 2020); the consumption of renewable energy, economic growth, and human development (Wang et al. 2018); renewable energy consumption, social and economic indicators such as GDP (Ergun et al. 2019). The motivation for the article is to present the relationship between selected indicators of innovation, socio-economic development, program data, and interest in the selected photovoltaic subsidy program in Poland.

According to the strategy of the European Green Deal (Communication EC 2019; Jasiński et al. 2021), the goal of achieving net-zero greenhouse gas emissions in the EU by 2050 has been set. Climate neutrality can be reached through several actions, including actively increasing the share of RES installations in the energy mixes of individual countries. In the National Plan for Energy and Climate for 2021-2030 (NECP PL 2019), Poland declared the achievement of a $21-23 \%$ share of renewable energy in the final gross energy consumption, while by the end of 2020, the share of renewable energy production should amount to $15 \%$ as the Polish RES target established in the Renewable Energy Directive (Directive EC 2009).

Poland, despite the successively increasing share of energy from renewable sources, still ranks behind in terms of the RES share in gross final energy consumption compared to other European countries (Fig. 1; Eurostat 2019). This indicator value for Poland in 2019 was 12.2\% and increased by $0.7 \%$ compared to 2018 (Fig. 2). An upward trend in the indicator has been 
observed since 2017, but these values are much lower than the average of the EU Member States (19.73\% in 2019).

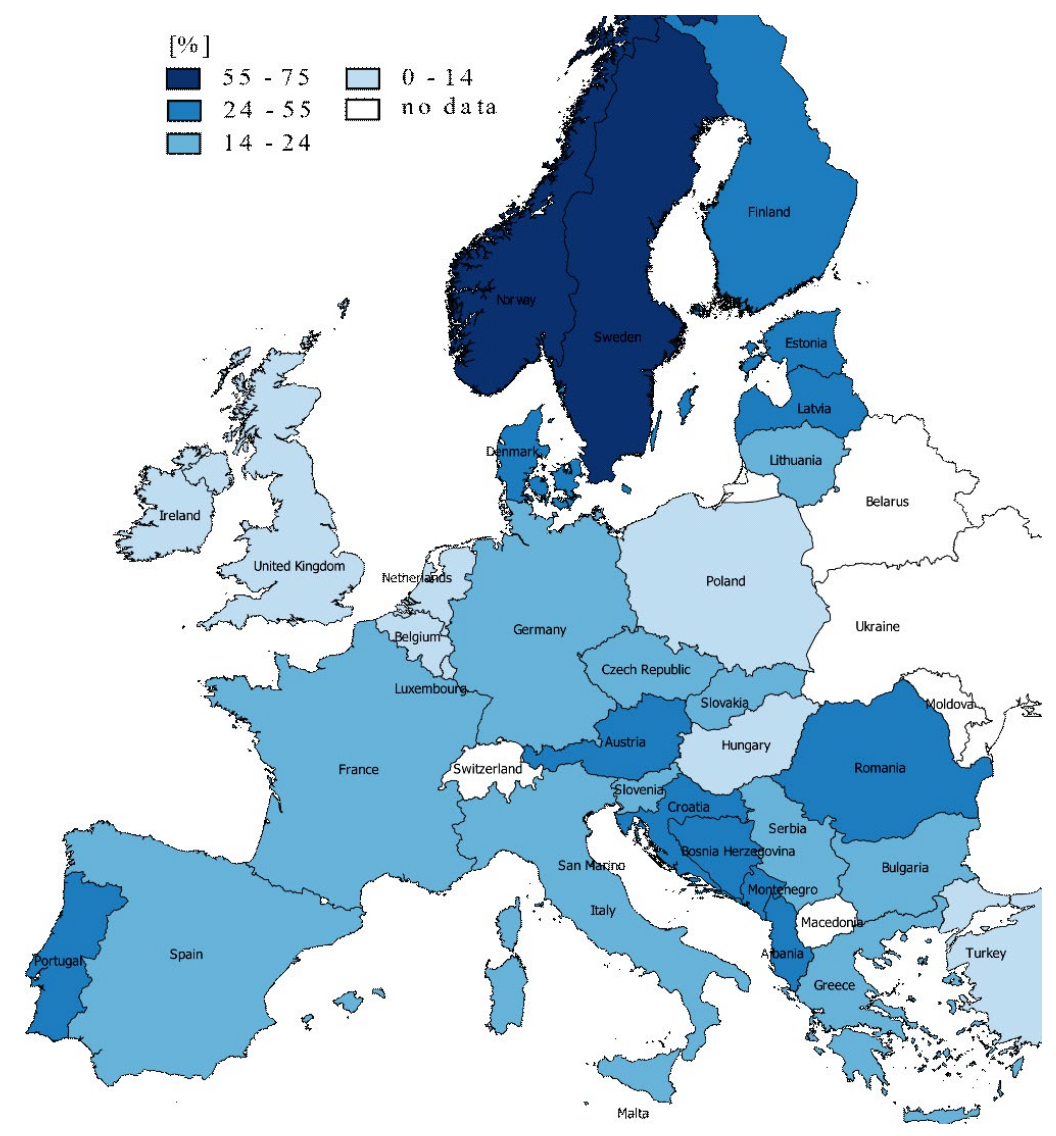

Fig. 1. Share of renewable energy in gross final energy consumption in Poland and EU countries in 2019 Source: own study based on (Eurostat 2019)

Rys.1. Udział energii odnawialnej w końcowym zużyciu energii brutto w Polsce i krajach UE w 2019 r.

The necessity to fulfill the obligations resulted in the introduction of a system of legal changes (amendment to the RES Acts, Act RES 2020) and financial incentives (subsidies such as "Mój Prąd" [My Electricity], Czyste Powietrze [Clean Air], Energia Plus [Energy Plus], Prosument [Prosumer or Agroenergia [Agroenergy]) by the Polish government, which were to convince public to use renewable energy, including photovoltaics (Wróbel et al. 2019). A key element of the energy transformation in the country, in accordance with the Poland Energy Policy until 2040 (PEP 2020), is the estimated increase in photovoltaic capacity, i.e. approx. 5-7 GW in 2030 and approx. 10-16 GW in 2040.

According to the data of Polskie Sieci Energetyczne (Polish Energy Networks), taking all photovoltaic installations operating in the national energy system into account, the installation 


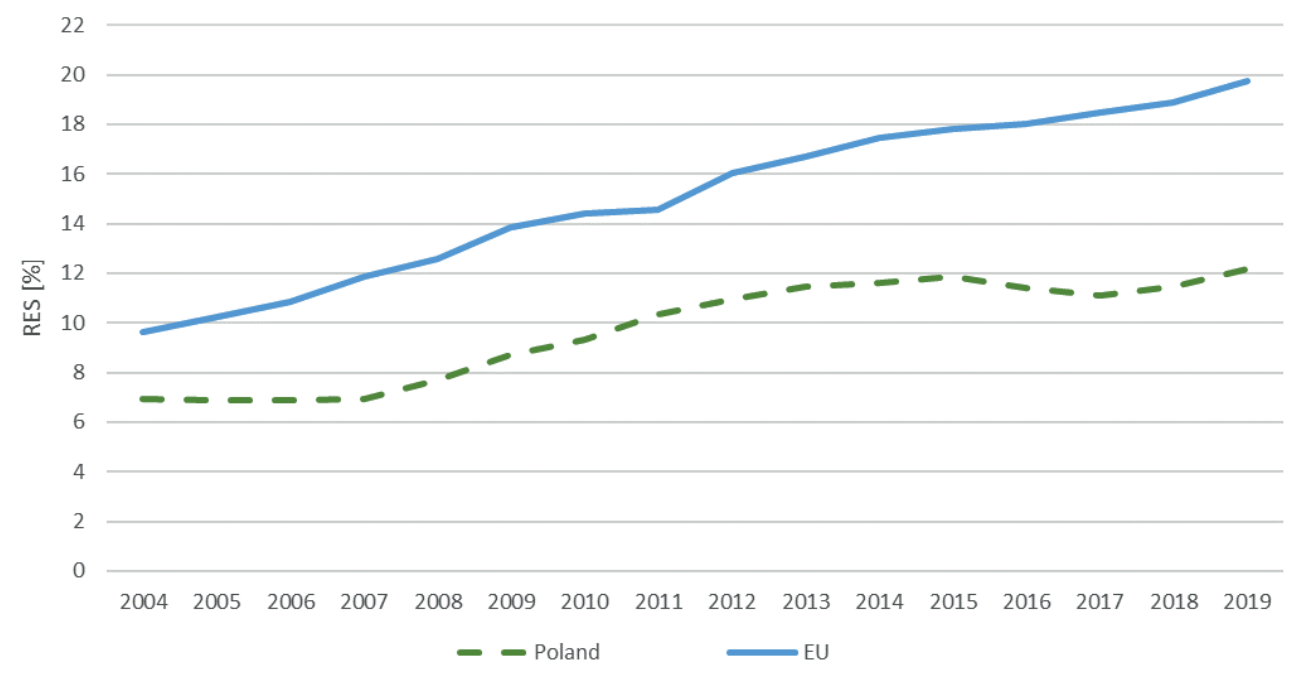

Fig. 2. Share of renewable energy in gross final energy consumption in Poland and EU countries between 2004-2019 Source: own study based on (Eurostat 2019)

Rys. 2. Udział energii odnawialnej w końcowym zużyciu energii brutto w Polsce i państwach UE w latach 2004-2019

capacity in 2019 was 1299.6 MWp, including approx. 275.7 MWp in small and large systems and 1040.9 MWp in micro-installations (SBF Polska PV 2020a). In 2019, the number of new photovoltaic micro-installations amounted to 105,953 which is almost a four-fold increase compared to 2018 (a total of 55,224 and 162,055 PV micro-installations in 2018 and 2019 respectively). According to estimates, the value of the photovoltaic micro-installations market at the end of 2019 exceeded PLN 2.8 bn (the value of installations above $50 \mathrm{kWp}$ is less than PLN 800 million). In the first half of 2020, the PV sector recorded dynamic growth (SBF Polska PV 2020b) despite the restrictions related to the COVID-19 pandemic. The capacity of new PV micro-installations was almost $13 \%$ higher than the capacity of connected micro-installations in all of 2019 and increased by $774.1 \mathrm{MWp}(112,420$ new installations). The total power of PV installations at the end of November 2020 was over 3.7 GWp (ARE 2021).

The "My Electricity" program is a significant stimulus for the development of prosumer energy (NFOŚiGW 2020), which is reflected in the increase in the power of micro-installations in recent years. The program, carried out so far in two editions in 2019 and 2020, guaranteed direct subsidies to photovoltaic micro-installations for households, while the allocation amount for co-financing was PLN 1.1 billion. The total amount of subsidies granted to photovoltaic micro-installations with an installed electrical capacity of $2 \mathrm{kWp}$ to $10 \mathrm{kWp}$ in the first edition was PLN 141 million for 28,437 applications, and in the second edition - PLN 382 million for 76,464 applications considered (lists published on 4/12/2020). The total installation capacity in the 2019 edition was $159.3 \mathrm{MWp}$ and in the 2020 edition until 4/12/2020 - 436.6 MWp.

Interest in the "My Electricity" program in individual provinces may vary, depending on socio-economic factors, technological and environmental resources, and the level of innovation. 
The research aims to compare provinces in Poland according to selected energy, environmental, innovation, and socio-economic indicators and to show how these factors affect individual interest in the "My Electricity" photovoltaic development program in provinces.

Previous research involving this type of analysis concerns data from the first edition (Olczak et al. 2020b) or partial data from the second edition of the "My Electricity" program (Olczak et al. 2021). The presented studies contain an analysis of data derived from the ranking lists of the first and second editions of the program (available on 4/12/2020) and are a continuation of previous research using the latest data. Moreover, the influence of the subsidy dependence on the province's Gross Domestic Product (GDP), Human Development Index (HDI), and Regional Innovation Scoreboard (RIS) indicators was demonstrated.

\section{Data and methods}

\subsection{Collecting data}

To understand the extent to which funding has an impact on the development of photovoltaics, various indicators were estimated for the amount of installed capacity under the program.

Selected innovation and energy indicators (on the scale of households) were chosen to compare provinces in Poland (Fig. 3). The presented studies showed how these indicators affect individual interest in the "My Electricity" photovoltaic development program. Moreover, the influence of the subsidy dependence on the province's GDP and HDI was demonstrated.

The correlation analysis for selected parameters has been used: program data (number of installations, installation power, grant value), demographic and social data (number of inhabitants, number of households), environmental data (insolation), energy data (total energy produced, energy from RES), socio-economic and innovation data (Gross Domestic Product - GDP, Human Development Index - HDI, and indicators from Regional Innovation Scoreboard 2017 RIS 2017).

The indicators related to the innovativeness of individual provinces (human resources, financial resources, employment, or sales impact) were obtained using the cyclical Regional Innovation Scoreboard report, which is an extension of the European Innovation Scoreboard. RIS includes a comparative evaluation assessment of the performance of innovation systems in 220 regions of the EU's 22 member states, Norway, Serbia, and Switzerland. Providing valuable additional information in terms of the comparability of Poland's provinces was possible based on 18 indicators (Table 1). RIS 2017 was used in the analyses due to the prospect of justifying the differentiation in the development of photovoltaics in subsequent years in the regional division. The publication uses data normalized on a scale of 0-1. The RIS 2017 report uses the administrative division of Poland into 16 provinces, while the next report from 2019 uses the current 


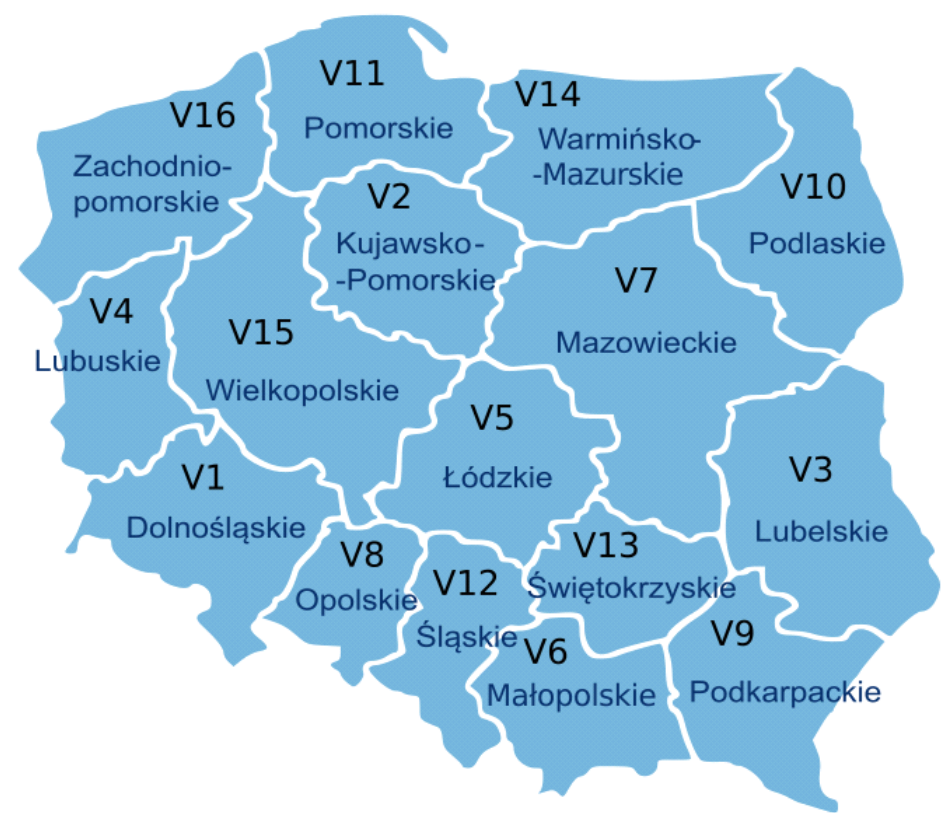

Fig. 3. Provinces of Poland along with the symbols used in the article Source: own study based on (GUGIK 2020)

Rys. 3. Województwa Polski wraz z symboliką stosowaną w artykule

NUTS 2 division of the Mazowieckie province into two independent regions, i.e. "Mazowiecki regionalny" and "Warszawski stołeczny", which prevents reliably comparison of indicators and justifies the use of the older report.

Also, the human development index - HDI was also used, describing changes in the socio-economic development of individual provinces (data for 2018, Table 1).

The analysis also included data from Statistics Poland for each province:

$\checkmark$ population in 2019 [mln] (Fig. 4),

\GDP-Gross Domestic Product in 2018 [PLN billion] (Fig. 4),

$\checkmark R E S$ - electricity production from Renewable Energy Source [TWh/year] (Fig. 5),

$\checkmark E C$ - electricity production [TWh/year] (Fig. 5),

$\checkmark$ number of households.

Data on the results of recruitment under the "My Electricity" program were also used (NFOŚiGW 2020):

$\checkmark$ grants [PLN mln] (Fig. 4),

$\checkmark N I-$ number of installation (Fig. 6),

$\checkmark P I-$ power installed under the program in the province $[\mathrm{Wp}]$.

$\downarrow A P I$ - average power installed under the program [Wp].

In addition, NASA MERRA and CM-SAF's SARAH dataset for insolation - Fig. 5 (Renewables 2019) was used.

102 


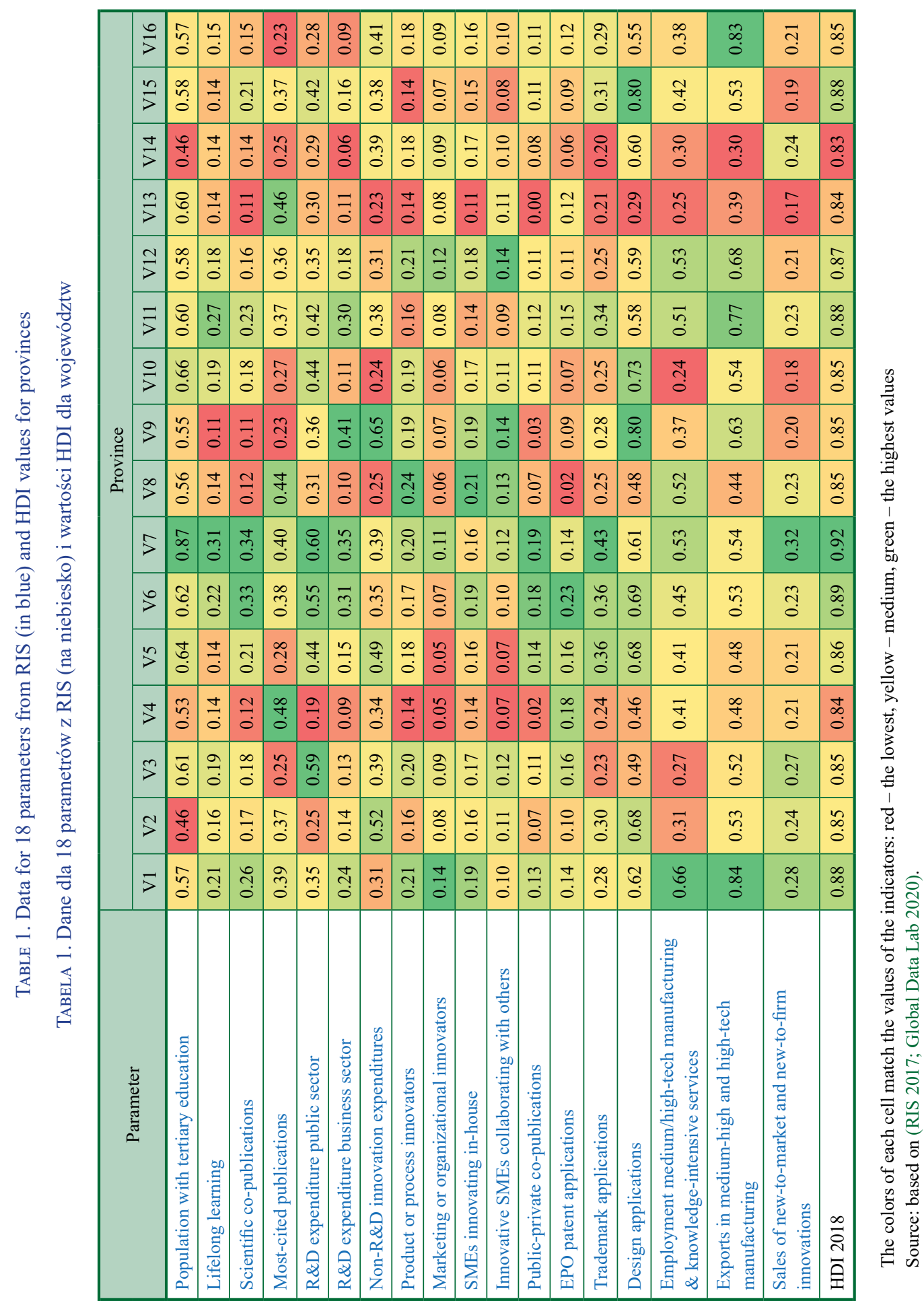




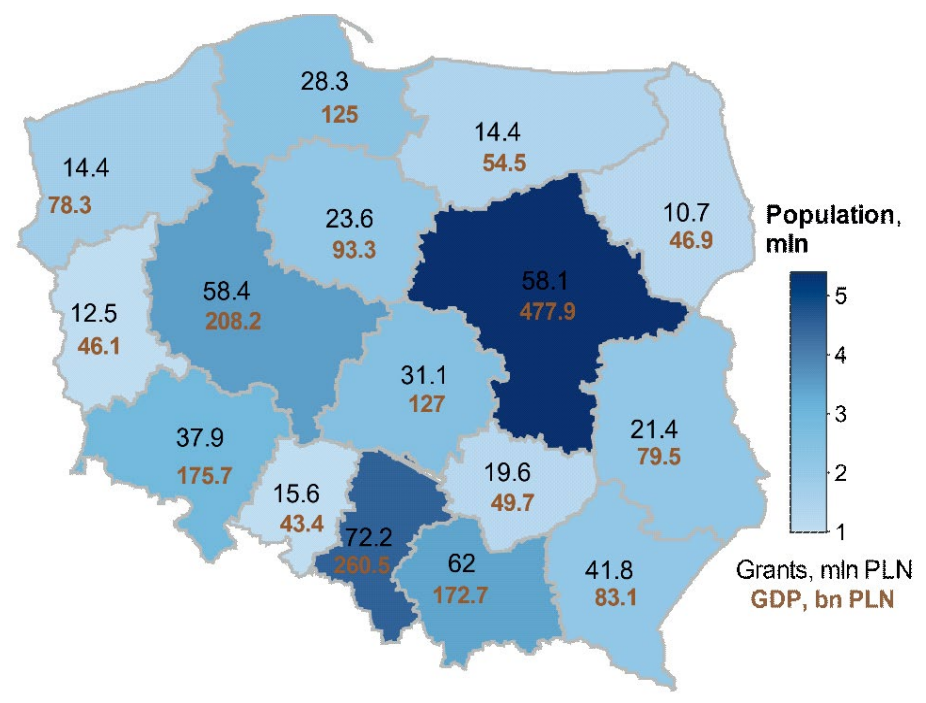

Fig. 4. Data on the population, Gross Domestic Product, and grants "My Electricity" program for each province Source: own study based on (CSO 2019; NFOŚiGW 2020)

Rys. 4. Dane o liczbie ludności, produkcie krajowym brutto oraz wartości dotacji w ramach programu „Mój Prąd” dla każdego województwa

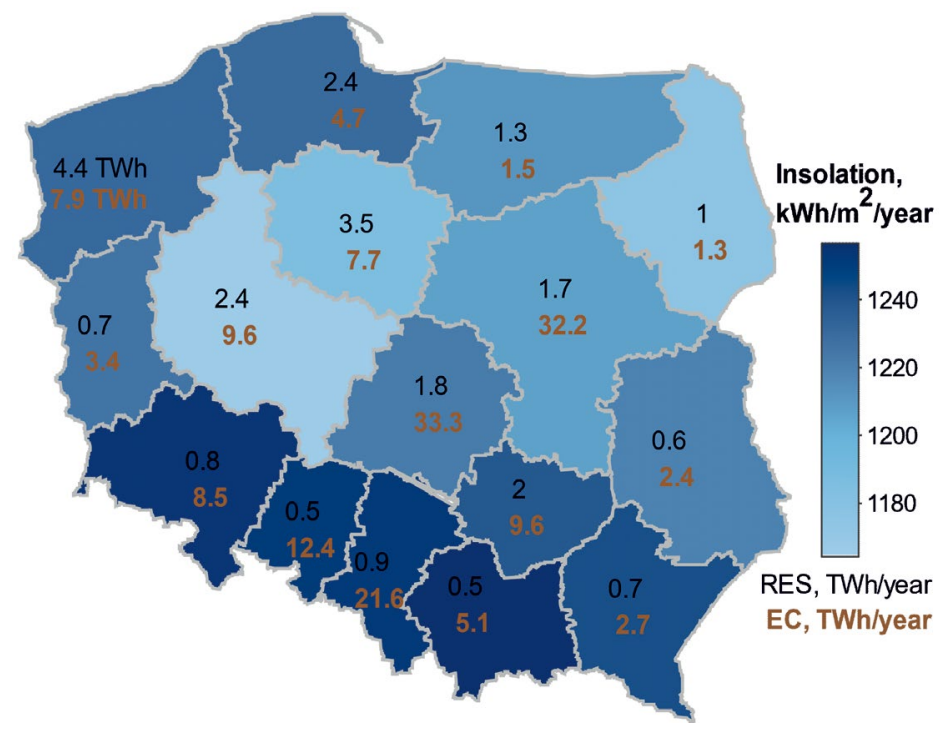

Fig. 5. Data on insolation, electricity production (EC), and electricity production in renewable energy installations (RES) for each province

Source: own study based on (Renewables 2019; CSO 2019)

Rys. 5. Dane o nasłonecznieniu, produkcji energii elektrycznej (EC), produkcji energii elektrycznej w instalacjach energii odnawialnej (RES) dla każdego województwa 


\subsection{Methods}

The analysis proceeded in two stages. First, the aggregated indicators for individual provinces were calculated, and then the correlation analysis was performed.

Initially, the power index per capita - Eq. 1 and household - Eq. 2 were calculated.

$$
P P I(\text { voiv. })=\frac{P I(\text { voiv. })}{\text { population }(\text { voiv. })}[\mathrm{Wp} / \text { inhab. }]
$$

where:

PPI - installation power indicator per inhabitant [Wp/inhab.],

$P I \quad-$ power installed under the program in the province $[\mathrm{Wp}]$.

Population - please see Figure 4.

$$
P P H(\text { voiv. })=\frac{P I(\text { voiv. })}{\text { number of households }(\text { voiv. })}[\mathrm{Wp} / \text { household }]
$$

where:

$P P H \quad-$ installation power indicator per household [Wp/ household],

$P I \quad-$ power installed under the program in the province [Wp]

Then the per capita grants rate - Eq. 3 and the rate of grants for Gross Domestic Product (Grants as a share of $G P D, G s G D P$ ) - Eq. 4 were calculated.

$$
G P I(\text { voiv. })=\frac{\text { Grants }(\text { voiv. })}{\text { population }(\text { voiv. })}[\mathrm{PLN} / \text { inhab. }]
$$

where:

GPI - grants per inhabitant [PLN/ inhab.],

Grants - sum of grants in "My Electricity" program, please see Figure 4.

$$
G s G D P(\text { voiv. })=\frac{\text { Grants }(\text { voiv. })}{G D P(\text { voiv. })}[\%]
$$

where:

GsGDP - Grants as a share of GPD,

Grants - the sum of grants in "My Electricity" program, please see Figure 4.

GDP - Gross Domestic Product, please see Figure 4.

The approximate value of the share of electricity produced in the installations created under the program was also calculated to the total value of electricity produced from RES in the pro- 
vince (PE_RES) - Eq.5; the calculations were made analogically for all energy produced in the province $\left(P E \_E\right)-$ Eq. 6.

$$
P E_{-} R E S=\frac{P I(\text { voiv. }) * \text { Insolation }(\text { voiv. })}{R E S(\text { voiv. })}
$$

where:

RES - electricity production from Renewable Energy Source (Fig. 5).

$$
P E_{-} E=\frac{P I(\text { voiv. }) * I n s o l a t i o n(\text { voiv. })}{E C(\text { voiv. })}
$$

where:

EC $\quad-$ electricity production (Fig. 5).

The results of the first part of the calculations in terms of PPI, PPH, PE_RES, PE_E, GPI, and GsGDP indicators are presented in Figures 6-8. The highest $P P I$ and $P P H$ (Fig. 6) was achieved in the Małopolskie province, i.e. $20.6 \mathrm{Wp} /$ inhabitant and $59.6 \mathrm{Wp}$ /household, respectively, and the lowest in Podlaskie province (9.9 Wp/inhabitant and $26.0 \mathrm{Wp}$ /household).

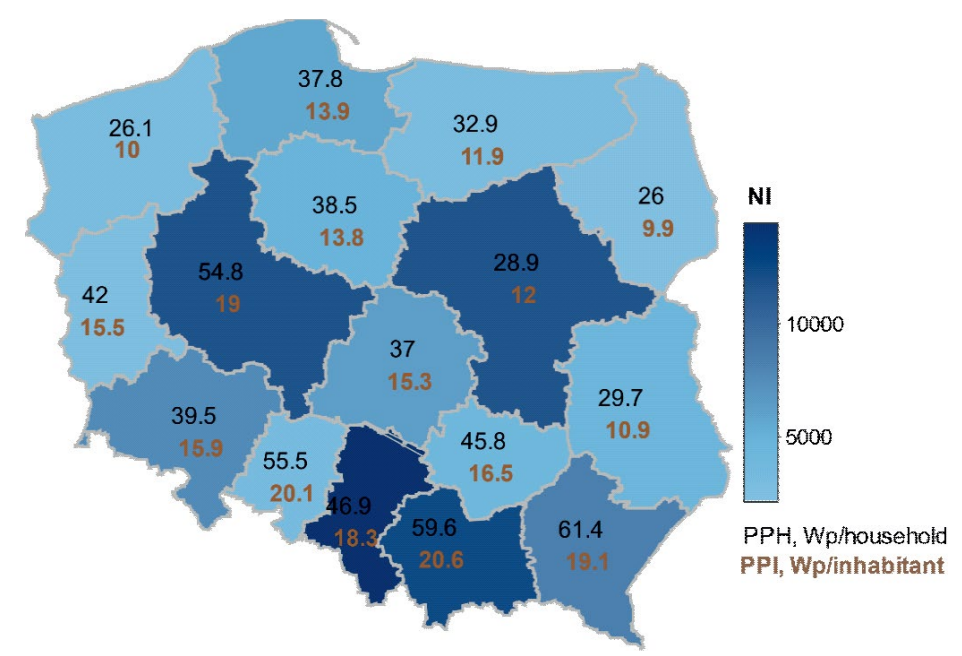

Fig. 6. Parameter values: PPH and PPI in provinces with the number of PV installations under the "My Electricity" (NI) program Source: own study based on (CSO 2019; NFOŚiGW 2020)

Rys. 6. Wartości parametrów: PPH i PPI w województwach na tle liczby instalacji PV powstałych w ramach programu „Mój Prąd” (NI)

The share of energy generated from the PV program in the total value of electricity produced from RES has the highest estimated value for the Małopolskie province (17.1\%, Fig. 7). The esti106 
mated energy to be produced from photovoltaic installations under the "My Electricity" program to the provincial electricity production was the highest in the Podkarpackie province (1.48\%).

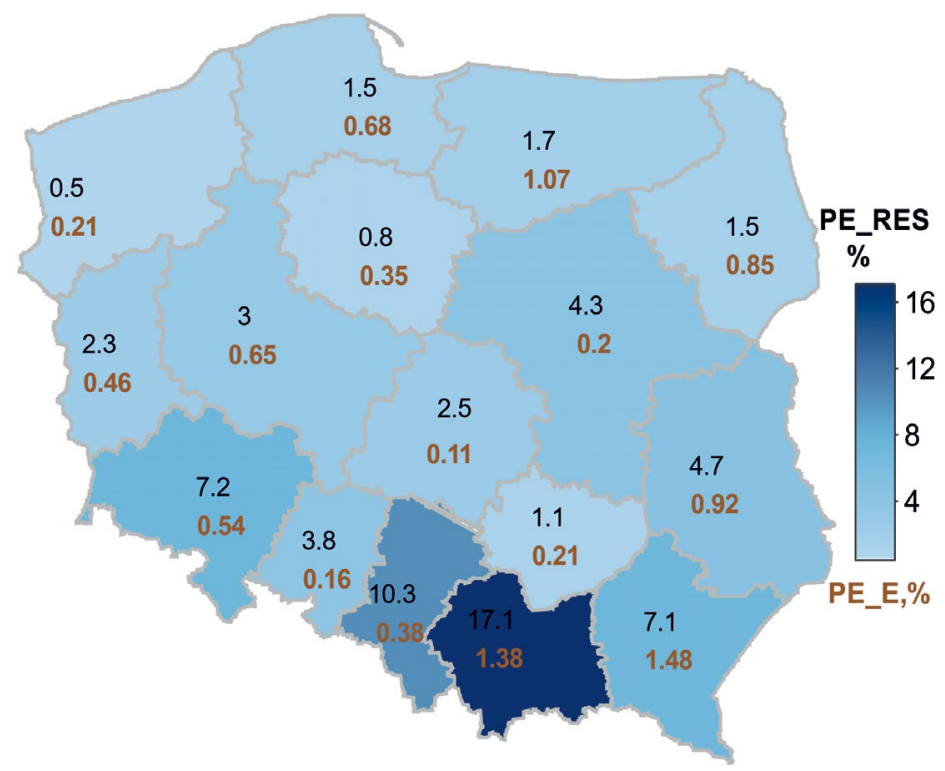

Fig. 7. Parameter values: $P E_{-} R E S$ and $P E \_E$ in provinces

Source: own study based on (CSO 2019; NFOŚiGW 2020)

Rys. 7. Wartości parametrów: $P E_{-} R E S$ i $P E_{-} E$ w województwach

The highest value of subsidy paid under the "My Electricity" program was accounted for in the Podkarpackie province as $0.05 \%$ of the total province's GDP (Fig. 8 ).

In the second part of the calculations, the correlation (Spearman) between the input data and the data calculated based on the results of the "My Electricity" program was analyzed - Eq. 7.

$$
r_{x y}=\frac{\frac{1}{n} \sum_{i}^{n}\left(R\left(x_{i}\right)-\overline{R(x)}\right)\left(R\left(y_{i}\right)-\overline{R(y)}\right)}{\sqrt{\left(\frac{1}{n} \sum_{i}^{n}\left(R\left(x_{i}\right)-\overline{R(x)}\right)^{2}\right)\left(\frac{1}{n} \sum_{i}^{n}\left(R\left(y_{i}\right)-\overline{R(y)}\right)^{2}\right.}}
$$

where:

$x \quad-$ parameter (data from Table 1 and GDP, population, EC, RES),

$y \quad-$ parameters calculated based on the results of the "My Electricity" program (API, PI, GsGDP, PPI, PPH, Grants, NI, GPI),

$R(x)$ and $R(y)$ - ranks of the $\mathrm{x}$ and $\mathrm{y}$ variables,

$R(x)$ and $R(y)$ - mean ranks,

$n \quad-$ number of observations (16). 


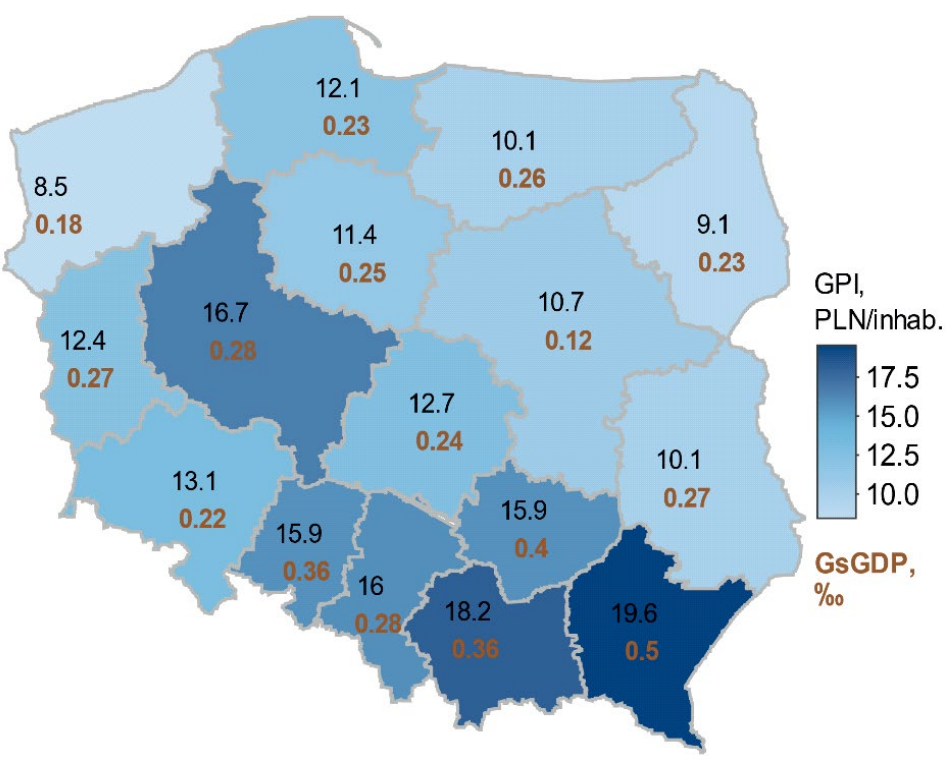

Fig. 8. Parameter values: GPI and GsGDP in provinces Source: own study based on (CSO 2019; NFOŚiGW 2020)

Rys. 8. Wartości parametrów: GPI i GsGDP w województwach

\section{Results and discussion}

The results of correlation analysis in accordance with the described methodology are presented in Table 2.

The population was closely correlated with the total installation power $(P I)$ in individual provinces (with a correlation coefficient - 0.91, Fig. 9) and the grant total value (0.90, Fig. 10). The population size has a theoretical positive impact on the installation power and subsidies values - the higher the population the greater the number of potential applicants for participation in the program. The presented values are mostly linear, except for the distinctive Mazowieckie Province. This is probably dependent on the fact that part of the province's population is concentrated in the capital of Poland (1.79 million to 5.42 million, CSO 2019) and what is related to the specificity of its buildings (urban predominance, a smaller number of individual households).

A significant relationship is also visible in the correlation of total installation power with Gross Domestic Product - Fig. 11 (0.91) and Human Developed Index - Fig. 12 (0.80). The main driving forces behind the increase in energy demand are the aforementioned population (its growth) and economic growth expressed by the Gross Domestic Product. In the case of the 


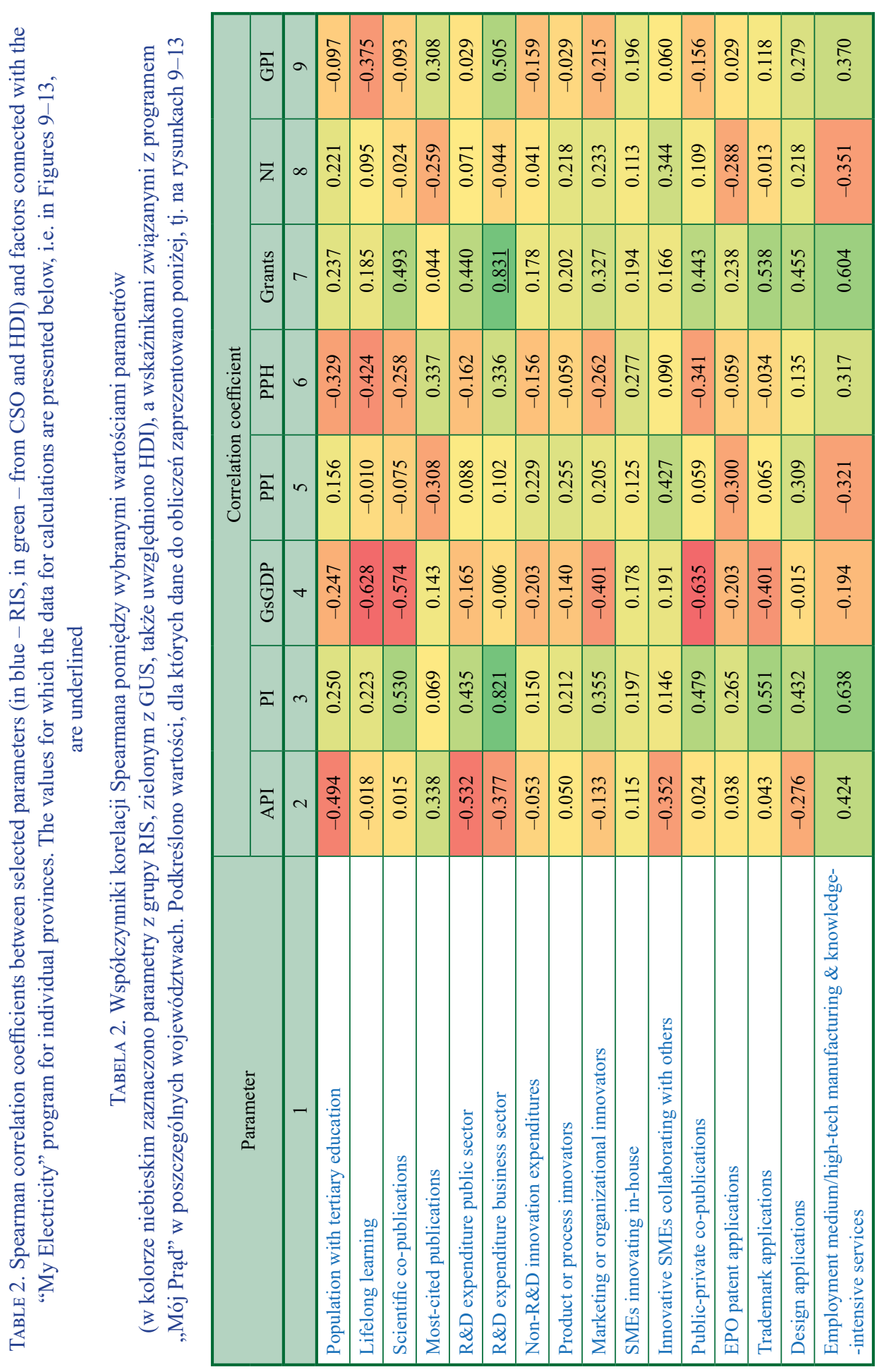




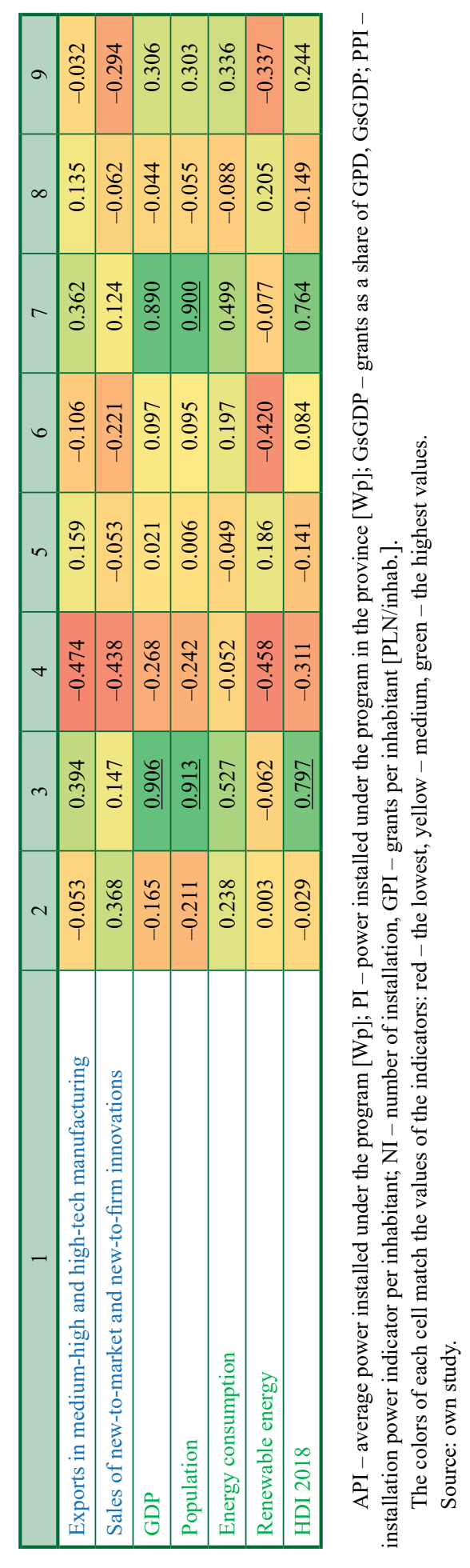




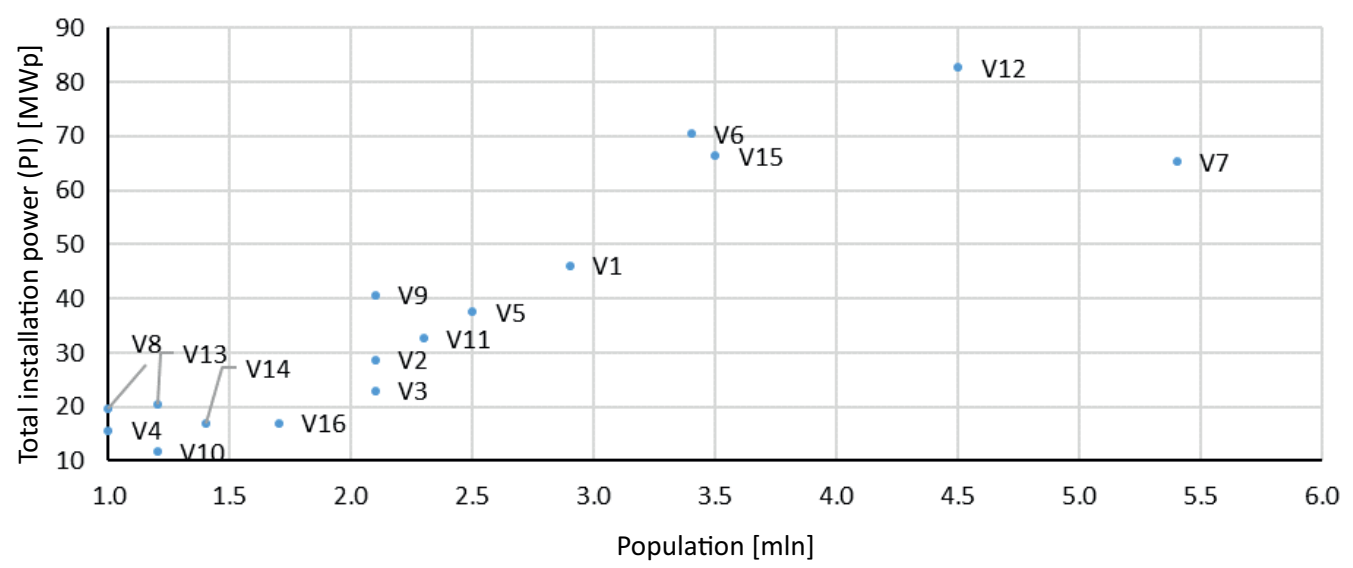

Fig. 9. Total installation power (PI) of photovoltaic panels as a function of the population in provinces Source: own study based on (CSO 2019; NFOŚiGW 2020)

Rys. 9. Całkowita moc zainstalowana paneli fotowoltaicznych w zależności od liczby ludności w województwie

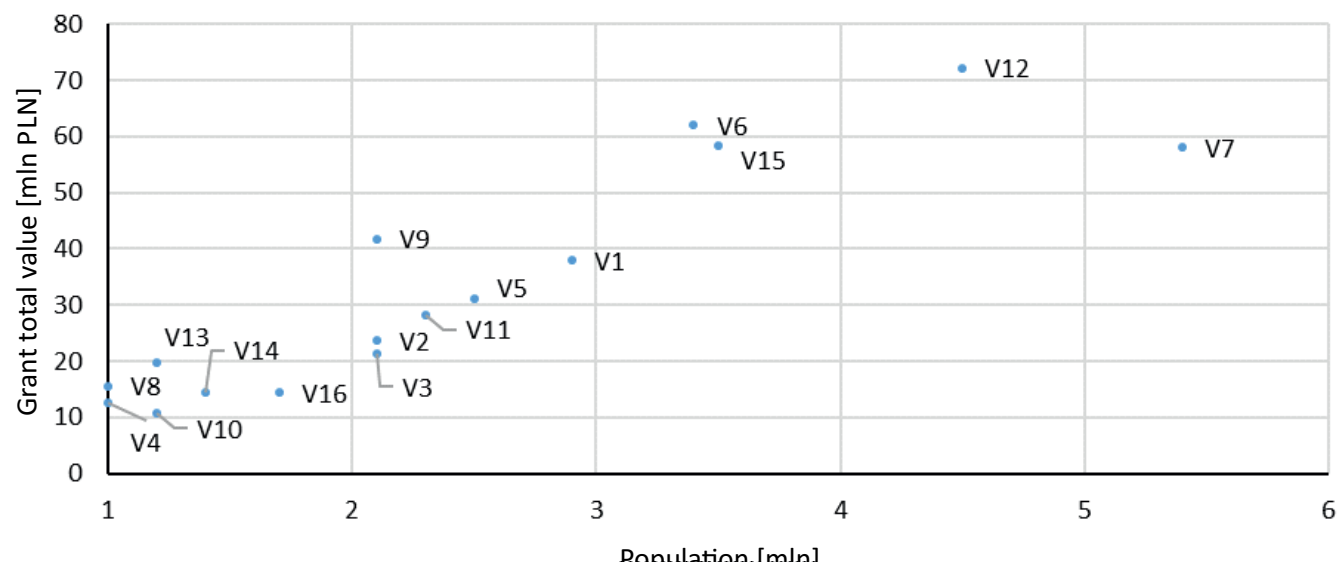

Fig. 10. Grant total value as a function of the population in provinces Source: own study based on (CSO 2019; NFOŚiGW 2020)

Rys. 10. Całkowita wartość dotacji w zależności od liczby ludności w województwie

Mazowieckie province, the previously mentioned specificity of this area causes a deviation from the linear trend. Renewable energy has a significant impact on human development. Countries invest in renewable energy, which increases the quality of the environment, and provides a kind of economic stability (no need to import fossil fuels, reduced dependence on exporters, no competition for exhaustive resources), which may have positive economic effects. For this reason, 


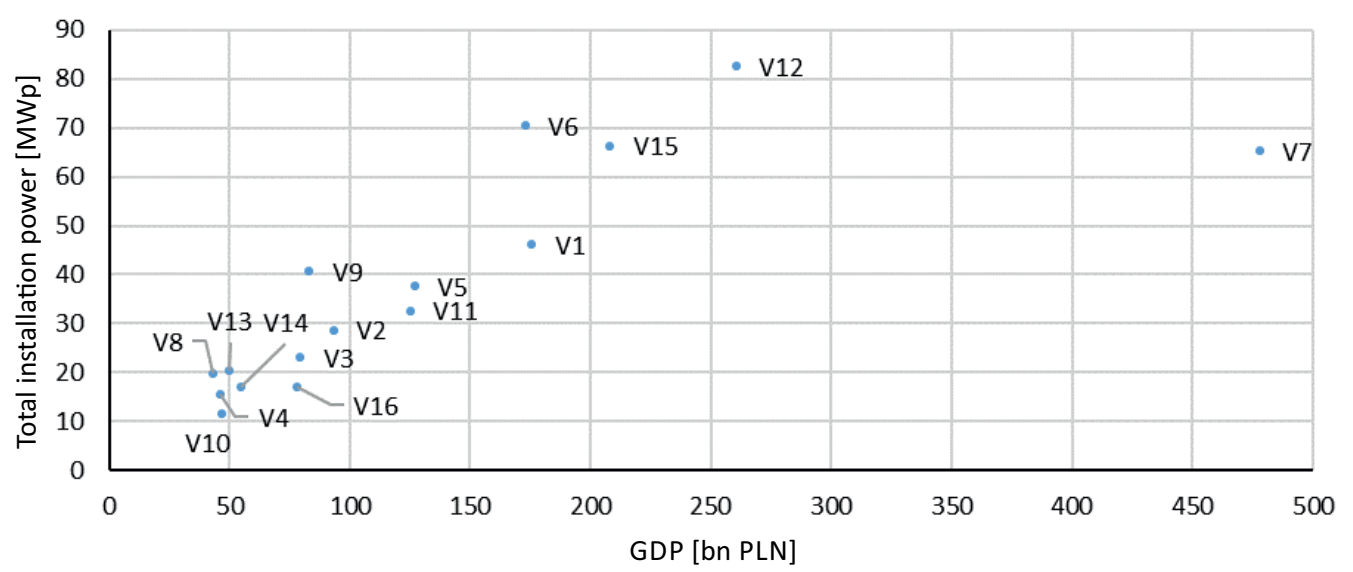

Fig. 11. Total installation power (PI) of photovoltaic panels as a function of Gross Domestic Product in provinces Source: own study based on (CSO 2019; NFOŚiGW 2020)

Rys. 11. Całkowita moc zainstalowana paneli fotowoltaicznych w zależności od produktu krajowego brutto w województwie

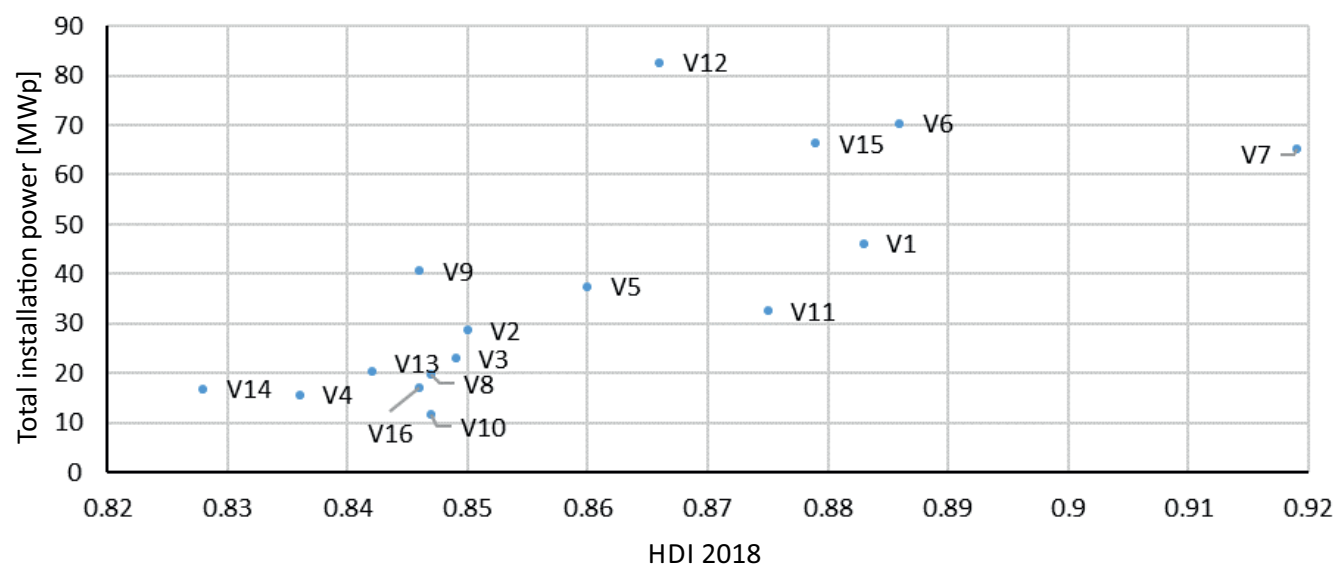

Fig. 12. Total installation power (PI) of photovoltaic as a function of HDI in provinces Source: own study based on (Global Data Lab 2020; NFOŚiGW 2020)

Rys. 12. Całkowita moc zainstalowana paneli fotowoltaicznych w zależności od wartości wskaźnika HDI 2018

components of the Human Development Index (HDI) such as health (life expectancy), education, and income may increase (this can be observed with a delay in time).

The highest correlation among all 18 analyzed innovation indicators from the Regional Innovation Scoreboard 2017 concerns the R\&D value of expenditure by the business sector with the grant total value - Fig. $13(0.83)$.

112 


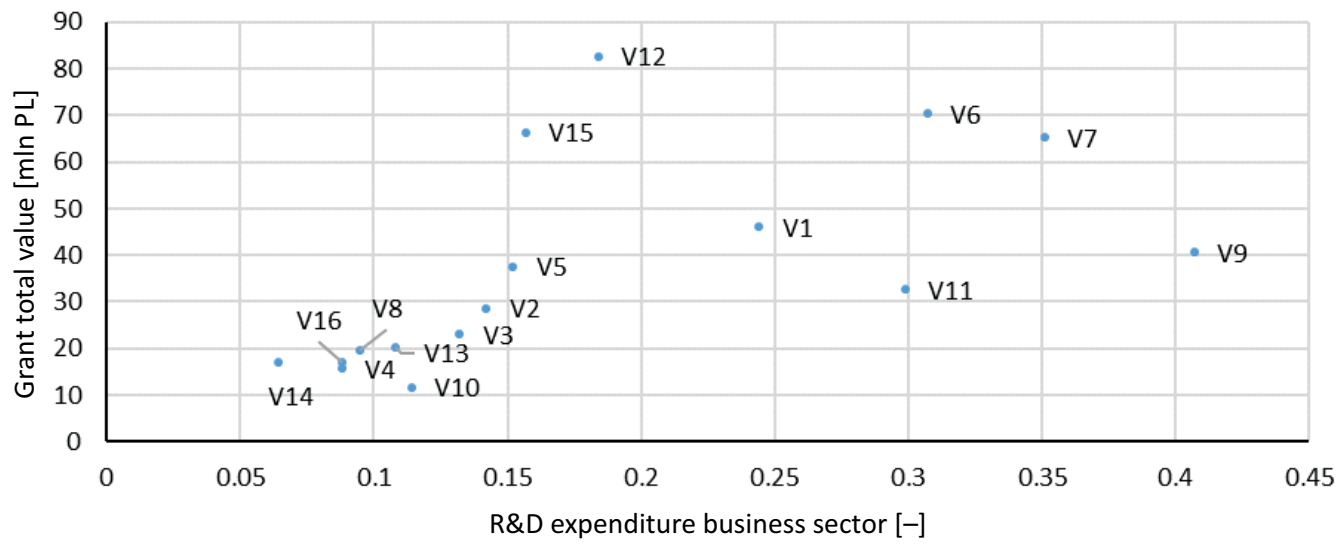

Fig. 13. Grant total value of photovoltaics as a function of "R\&D expenditure business sector" RIS factor in provinces Source: own study based on (NFOŚiGW 2020; RIS 2017)

Rys. 13. Całkowita wielkość dotacji w zależności od wydatków w sektorze biznesowym na badania i rozwój

\section{Conclusions}

Actions to increase the production of photovoltaic energy are key to achieving the national targets and the EU target for the share of energy from renewable sources. The photovoltaic grant support "My Electricity" was Poland's flagship program in the field of renewable energy under the Green Deal. The existing funds showed that the "My Electricity" program may increase the share of renewable energy in the energy consumed by approx. 0.3 percentage points and the entire program (for which PLN 1.1 billion was allocated) is estimated that will yield 0.6 percentage points.

Public involvement in participation in subsidy programs may depend on a variety of economic, environmental, technological, and innovative factors that were analyzed in the study. The highest correlation is visible in the following indicators: total installation power and population (0.91), total grants value and population (0.90); total installation power and GDP (0.78); grants value and GDP (0.77); total installation power and HDI (0.75). From the RIS indicators, the highest correlation coefficient with the photovoltaic development indicators was achieved for "R\&D expenditure in the business sector" $(0.62)$. Renewable energy not only benefits the environment but also improves the means of social development.

In connection with the above-mentioned results, it is estimated that the increase in the value of indicators such as HDI, "R\&D expenditure in the business sector" or GDP will positively affect the popularity of investments in RES in provinces. Such a significant increase during the 
duration of one subsidy program (e.g. 2 years) is obviously not possible, but the demonstrated relationships can be used in determining the long-term policy of a state or region. Moreover, when designing this type of subsidy program (such as My Electricity) in the future, additional criteria should be considered to balance the popularity of PV micro-installations between provinces.

This research was realized within statutory activities of the Mineral and Energy Economy Research Institute of the Polish Academy of Sciences.

\section{References}

Act RES 2020. Act of July 16, 2020 amending the Renewable Energy Sources Act (Ustawa z dnia 16 lipca 2020 r. o zmianie ustawy o odnawialnych źródłach energii) (Dz.U. 2020 poz. 1503) (in Polish).

Allied Market Research 2019 Photovoltaic Market by Technology and Application: Global Opportunity Analysis and Industry Forecast, 2019-2026. Market Report. 342 pp. (summary).

ARE 2021. Photovoltaics has a capacity of over $3.7 \mathrm{GW}$ (Fotowoltaika osiagnęla moc ponad 3,7 GW). [Online] https://www.rynekelektryczny.pl/moc-zainstalowana-fotowoltaiki-w-polsce/ [Accessed: 2021-01-12] (in Polish).

Canales et al. 2020 - Canales, F.A., Jadwiszczak, P., Jurasz, J., Wdowikowski, M., Ciapala, B. and KAŹmierczaK, B. 2020. The impact of long-term changes in air temperature on renewable energy in Poland. Science of the Total Environment 729, 138965, pp. 1-21, DOI: 10.1016/j.scitotenv.2020.138965.

Communication EC 2019. Communication from the Commission to the European Parliament, the European Council, the Council, the European Economic and Social Committee and the Committee of the Regions. The European Green Deal. COM(2019) 640, Brussels, 11 December 2019.

CSO 2019. Central Statistical Office - Local Data Bank. [Online] https://bdl.stat.gov.pl/BDL/dane/podgrup/temat [Accessed: 2020-12-04].

Directive EC 2009. Directive 2009/28/EC of the European Parliament and of the Council of 23 April 2009 on the promotion of the use of energy from renewable sources and amending and subsequently repealing Directives 2001/77/EC and 2003/30/EC.

Ergun et al. 2019 - Ergun, S., Owusu, P. and Rivas, M. 2019. Determinants of renewable energy consumption in Africa. Environmental Science and Pollution Research 26, pp. 15390-15405, DOI: 10.1007/s11356-019-04567-7.

Eurostat 2019. Share of renewable energy in gross final energy consumption. [Online] https://ec.europa.eu/ eurostat/web/products-datasets/-/t2020_rd330 [Accessed: 2021-01-04].

Global Data Lab 2020. Subnational Human Development Index (4.0). [Online] https://globaldatalab.org/ shdi/shdi/ [Accessed: 2020-12-10].

GUGIK 2020. SBR - administrative units (PRG-jednostki administracyjne). [Online] http://www.gugik. gov.pl/pzgik/dane-bez-oplat/dane-z-panstwowego-rejestru-granic-i-powierzchni-jednostek-podzialow -terytorialnych-kraju-prg [Accessed: 2020-12-10] (in Polish).

JASIŃSKI et al. 2021 - JASIŃSKI, J., KoZAKIEwICZ, M. and SoŁTYSIK, M. 2021. Determinants of Energy Cooperatives' Development in Rural Areas - Evidence from Poland. Energies 14(319), pp. 1-19, DOI: 10.3390/en140203.

KAZAR, G. and KAZAR, A. 2014. The renewable energy production-economic development nexus. International Journal of Energy Economics and Policy 4(2), pp. 312-319. 
Lin, R. and REN, J. 2020. Renewable Energy and Sustainable Development. Journal of Renewable Energy and Sustainable Development 6(1), pp. 3-7, DOI: 10.21622/resd.2020.06.1.003.

NECP PL 2019. National Energy and Climate Plan for the years 2021-2030 of 18 December 2019 (Krajowy plan na rzecz energii i klimatu na lata 2021-2030 z dnia 18 grudnia 2019). Ministry of State Assets (in Polish).

NFOŚiGW 2020. My Electricity program - recruitment results (Program Mój Prąd-wyniki naboru). [Online] https://mojprad.gov.pl/wyniki-1-naboru-2019/ [Accessed: 2020-12-04] (in Polish).

Olczak et al. 2020a - OlczaK, P., OleK, M. and Kryzia, D. 2020. The ecological impact of using photothermal and photovoltaic installations for DHW preparation. Polityka Energetyczna - Energy Policy Journal 23(1), pp. 65-74, DOI: 10.33223/epj/118999.

Olczak et al. 2020b - Olczak, P., Matuszewska, D. and Kryzia, D. 2020. "Mój Prąd" as an example of the photovoltaic one off grant program in Poland. Polityka Energetyczna - Energy Policy Journal 23(2), pp. 123-138, DOI: 10.33223/epj/122482.

Olczak et al. 2021 - Olczak, P., Kryzia, D., Matuszewska, D. and Kuta, M. 2021. "My Electricity" Program Effectiveness Supporting the Development of PV Installation in Poland. Energies 14, 231, pp. 1-16, DOI: 10.3390/en14010231.

PEP 2020. Poland's Energy Policy until 2040 - the presentation (Polityka energetyczna Polski do $2040 \mathrm{r}$ - prezentacja). Ministry of Climate (in Polish).

Østergaard et al. 2020 - Østergaard, P. A., Duic, N., Noorollahi, Y., Mikulcic, H. and Kalogirou, S. 2020. Sustainable development using renewable energy technology. Renewable Energy 146, pp. 2430-2437, DOI: 10.1016/j.renene.2019.08.094.

Renewables 2019. Renewables.ninja - insolation. [Online] https:/www.renewables.ninja/ [Accessed: 2020-12-04].

RIS 2017. Regional Innovation Scoreboard 2017. Directorate-General for Internal Market, Industry, Entrepreneurship and SMEs (European Commission). Publications Office of the European Union, 84 pp., DOI: $10.2873 / 593800$.

Sasmaz et al. 2020 - Sasmaz, M.U., Sakar, E., Yayla, Y.E. and Akkucuk, U. 2020. The Relationship between Renewable Energy and Human Development in OECD Countries: A Panel Data Analysis. Sustainability 12(18), 7450, pp. 1-16, DOI: 10.3390/su12187450.

SBF Polska PV 2020a. Photovoltaic Microinstallation Market Poland '19 - as of December 31, 2019 (Rynek Mikroinstalacji Fotowoltaicznych Polska '19 - stan na 31 grudnia 2019). Stowarzyszenie Branży Fotowoltaicznej Polska PV, 19 pp. (in Polish).

SBF Polska PV 2020b. Photovoltaic Microinstallation Market in Poland H1 2020 - as of June 30 (Rynek Mikroinstalacji Fotowoltaicznych w Polsce I polowa '20 - stan na 30 czerwca). Stowarzyszenie Branży Fotowoltaicznej Polska PV (in Polish).

WANG et al. 2018 - WANG, Z., DANish, Zhang, B. and WANG, B. 2018. Renewable energy consumption, economic growth, and human development index in Pakistan: Evidence form a simultaneous equation model. Journal of Cleaner Production 184, pp. 1081-1090, DOI: 10.1016/j.jclepro.2018.02.260.

Wróbel et al. 2019 - Wróbel, J., SoŁtysiK, M. and Rogus, R. 2019. Selected elements of the Neighborly Exchange of Energy - Profitability evaluation of the functional model. Polityka Energetyczna - Energy Policy Journal 22(4), pp. 53-64, DOI: 10.33223/epj/112508. 


\section{Regionalne zależności w zakresie zainteresowania programem dotacji fotowoltaiki „Mój Prąd” w Polsce}

\section{Streszczenie}

W ciągu niecałej dekady sektor fotowoltaiczny przekształcił się w globalny biznes. Dynamika jego rozwoju jest zróżnicowana w zależności od państwa. Według szacunków wartość rynku mikroinstalacji fotowoltaicznych w Polsce na koniec 2019 roku przekroczyła 2,8 mld zł.

W I półroczu 2020 roku dynamicznie rozwijał się sektor PV, dla którego łączna moc mikroinstalacji wyniosła 2,5 GWp. Dotacje rządowe były jednym z czynników przyczyniających się do ekspansji sektora PV.

W Polsce istnieje wiele możliwości finansowych zintensyfikowania budowy nowych instalacji odnawialnych źródeł energii, m.in.: system taryf, dotacje, pożyczki. Przykładem wsparcia w postaci dotacji dla rozwoju fotowoltaiki w Polsce jest stworzony w 2019 roku program „Mój Prąd” z budżetem 1,1 mld zł.

Zainteresowanie programem „Mój Prąd” w poszczególnych województwach może być zróżnicowane w zależności od czynników społeczno-ekonomicznych, zasobów technologicznych i środowiskowych oraz poziomu innowacyjności. Motywacją dla powstania artykułu było porównanie województw w Polsce według wybranych wskaźników energetycznych, społeczno-ekonomicznych, środowiskowych i innowacyjności oraz analiza wpływu tych czynników na zainteresowanie programem rozwoju fotowoltaiki „Mój Prąd" w województwach.

Występuje wysoka korelacja dla całkowitej mocy instalacji w ramach programu „Mój Prąd” oraz produktu krajowego brutto (PKB) i wskaźnika rozwoju społecznego (HDI). Najwyższy współczynnik korelacji spośród wskaźników RIS i danych programowych dotacji uzyskano dla „nakładów na działalność badawczo-rozwojową w sektorze przedsiębiorstw”. Liczba ludności była ściśle skorelowana z łączną mocą instalacji oraz wartością dotacji w ramach programu „Mój Prąd”.

SŁowa KLUCzowE: fotowoltaika, energia odnawialna, program „Mój Prąd”, analiza korelacyjna, wskaźniki RIS 